\title{
Effects of Tillage and Planting Methods on Narrow and Wide Row Cotton Production
}

\author{
Michael W. Marshall'1, Ahmad Khalilian² \\ ${ }^{1}$ Clemson University, Edisto Research and Education Center, Blackville, SC, USA \\ ${ }^{2}$ Clemson University, Department of Agricultural Sciences, Clemson, SC, USA \\ Email:marsha3@clemson.edu, akhlln@clemson.edu
}

How to cite this paper: Marshall, M.W. and Khalilian, A. (2018) Effects of Tillage and Planting Methods on Narrow and Wide Row Cotton Production. Agricultural Sciences, 9, 792-803.

https://doi.org/10.4236/as.2018.97056

Received: June 8, 2018

Accepted: July 13, 2018

Published: July 16, 2018

Copyright ( 92018 by authors and Scientific Research Publishing Inc. This work is licensed under the Creative Commons Attribution International License (CC BY 4.0).

http://creativecommons.org/licenses/by/4.0/

(c) (i) Open Access

\begin{abstract}
Cotton (Gossypium hirsutum L.) is an economically important crop for the Southern United States. The southern US also has a long growing season suitable for double cropping a second crop after small grains; however, the harvest date for the small grains typically occurs after the optimum planting window for cotton which reduces yield potential. A relay intercropping system was developed at Clemson University that allows interseeding of cotton into standing wheat 2 to 3 weeks before harvest with interseeded cotton yields similar to the conventional mono-cropped cotton. Therefore, the objectives of this study were 1) to determine the optimum tillage and planting methods for narrow row $(76-\mathrm{cm})$ and wide row $(97-\mathrm{cm})$ cotton, and 2) to compare narrow and wide row systems for conventional tillage cotton, cotton interseeded into standing wheat, and cotton planted into a terminated wheat cover crop on coastal plain soil. Two replicated tests were conducted to accomplish these objectives. In Study 1, conventional narrow row cotton combined with a deep tillage operation using Paratill yielded 23\% more than conventional wide row cotton which had a deep tillage operation with a subsoiler just before planting. There were no differences between the conventional (97- $\mathrm{cm}$ row spacing) mono-crop and interseeded cotton yields. In Study 2, there was no significant difference in yield between narrow-row and wide-row cotton for each cropping system during the two years study. Both wide and narrow-row full season cotton had significantly higher yields than interseeded and cover crop planting systems in year two of the study. The two conservation cropping practices, wheat used as a cover crop and interseeding, showed considerable promise for reducing energy requirements, soil erosion, and wind-borne cotton damage associated with bare soil in conventional tillage. This research demonstrates the benefits of interseeding and narrow row spacing for sustainable cotton production in coastal plain soils of the Southern United States.
\end{abstract}




\section{Keywords}

Conservation, Relay Cropping, Interseeding, Double Crop, Cotton, Row Spacing

\section{Introduction}

The production value of cotton is ranked as one of the most economically important cropping system in the southern USA with an estimated value of over \$7 billion [1]. The southern US growing season is typically longer than other parts of the US which makes doubling cropping summer crops after the harvest of the winter crop, such as wheat a viable practice. Double-cropping or planting of cotton after wheat harvest (around early June) occurs after the optimum planting window (early to mid-May) which often limits the yield potential of cotton. Cotton requires a longer growing season for optimum yields and has limited options for shorter season varieties compared to soybean (Glycine max L.) which is the traditional crop in the Southern US that is planted after wheat harvest.

A double-cropping planter/drill system developed at Clemson University allows interseeding or planting of one crop, such as cotton, into a second crop, such as winter wheat two to three weeks before the harvest of the second crop [2] [3]. All field operations, including planting of wheat, fertilizer application, pesticide application, and wheat harvest, utilize the same wheel traffic lanes to prevent soil compaction in the interseeding plant growth zones. In addition, interseeded cotton does not need spring deep tillage because of the fall deep tillage conducted before wheat planting [3] [4].

The availability of cotton pickers with adjustable width headers that can harvest cotton grown on multiple row patterns (i.e., from 76- to 97-cm) has renewed interest in narrow-row cotton production systems. The critical period for weed control in cotton is relatively long, especially when grown on wide rows $(97-\mathrm{cm}$ or wider) because of the time required for the canopy to close the row middles [5]. Narrow-row cotton significantly reduces the period of time for the canopy to shade out the row middles; thereby, reducing the number of herbicide applications for weed management [5]. It also enables cotton plants to utilize more sunlight prior to closure of the plant canopy [6]. Previous research has indicated that narrow-row cotton may increase yield [7] [8] [9].

Interseeding cotton into wheat is a practice that has potential conservation, economic and soil-management advantages. Previous research conducted in South Carolina showed no significant differences in yield between cotton interseeded into standing wheat two weeks before wheat harvest and conventional, mono-cropped, cotton production [2] [3]. In addition, no differences were observed in cotton quality factors between conventionally grown and interseeded cotton [3]. Cotton was planted in the wide row configuration $(97-\mathrm{cm})$ using either a John Deere 1700 narrow row planter or the Clemson interseeder plan- 
ter/no-till drill, with various row spacing patterns. The Clemson interseeder row pattern configurations are extremely flexible because it can plant both the winter wheat crop in the fall and intercrop cotton the following spring into the standing wheat crop with minimal impact on the wheat. The objectives of this study were 1) to determine the optimum tillage/planting methods for narrow row $(76-\mathrm{cm})$ and wide row $(97-\mathrm{cm})$ cotton, and 2) to compare narrow and wide row systems for conventional tillage cotton, cotton interseeded into standing wheat, and cotton planted in a killer wheat cover crop on coastal plain soil.

\section{Materials and Methods}

\subsection{Study 1}

Replicated field experiments were conducted at the Clemson University Edisto Research and Education Center $\left(33.36^{\circ} \mathrm{N}, 81.32^{\circ} \mathrm{W}\right)$ near Blackville, SC, USA to evaluate the effects fall and spring deep tillage operations on two different interseeding row patterns: narrow row system (Figure 1) compared to wide row interseeding system (Figure 2). The experiments were arranged in a randomized complete block design with six replications. Soil type was a Varina loamy sand soil (clayey, kaolinitic, thermic plinthic Paleudults). This is a highly productive soil typically found in the southeastern Coastal Plain region. The treatments for Study 1 are presented in Table 1 . Cotton variety "DES 119" was seeded at $1.3 \mathrm{~cm}$ depth at approximately 7 to 13 seeds per $m$ row for the conventional plots and 13 to 20 seeds per $\mathrm{m}$ row in the interseeded and cover-crop treatments around Mid-May approximately two weeks before wheat maturity. Plots dimension were 3.9 by $30 \mathrm{~m}$. Wheat was harvested during the first week in June. The grain combine was equipped with a straw deflector, which placed the straw in the tractor and combine wheel track to aid in residue management and weed control. This feature also prevented placing excess straw on top of the young cotton seedlings

Table 1. Tillage and planting treatments at 76 and $97-\mathrm{cm}$ row spacing in Study 1.

\begin{tabular}{|c|c|c|c|c|c|}
\hline TRT & Fall tillage & Spring tillage & Planter & Interseeded $^{1}$ & Row spacing \\
\hline & & & & & $\mathrm{cm}$ \\
\hline 1 & Paratill $^{2}$ & None & Interseeder $(\mathrm{W})^{3}$ & Yes & 97 \\
\hline 2 & Paratill $^{2}$ & None & Interseeder $(\mathrm{N})^{3}$ & Yes & 76 \\
\hline 3 & Subsoiler ${ }^{4}$ & None & Interseeder $(\mathrm{N})^{3}$ & Yes & 76 \\
\hline 4 & None & Disk/Subsoil/Bed ${ }^{5}$ & J.D. 7000 & No & 97 \\
\hline 5 & None & Paratill & J.D. $71(5)^{6}$ & No & 76 \\
\hline
\end{tabular}

${ }^{1}$ Otton interseeded into standing wheat (Figure 3). ${ }^{2}$ Paratill (Bigham Ag, Lubbock, TX, USA) with 61-cm shank spacing operating 30- to 33-cm deep. ${ }^{3}$ Clemson interseeder planter/no-till drill [3]. $\mathrm{N}=$ narrow row (Figure 1) and $\mathrm{W}=$ wide row (Figure 2). ${ }^{4}$ Subsoiler shank with $38-\mathrm{cm}$ shank spacing operating 30 to $33-\mathrm{cm}$ deep. ${ }^{5}$ Conventional tillage consisted of a disk harrow followed by a subsoiler bedder operating 30 - to $33-\mathrm{cm}$ deep followed by striking-off beds with bed knockers and planting the cotton. ${ }^{6}$ Five-row John Deere 71 planter units (John Deere Co., Moline, IL, USA) (Figure 4). 


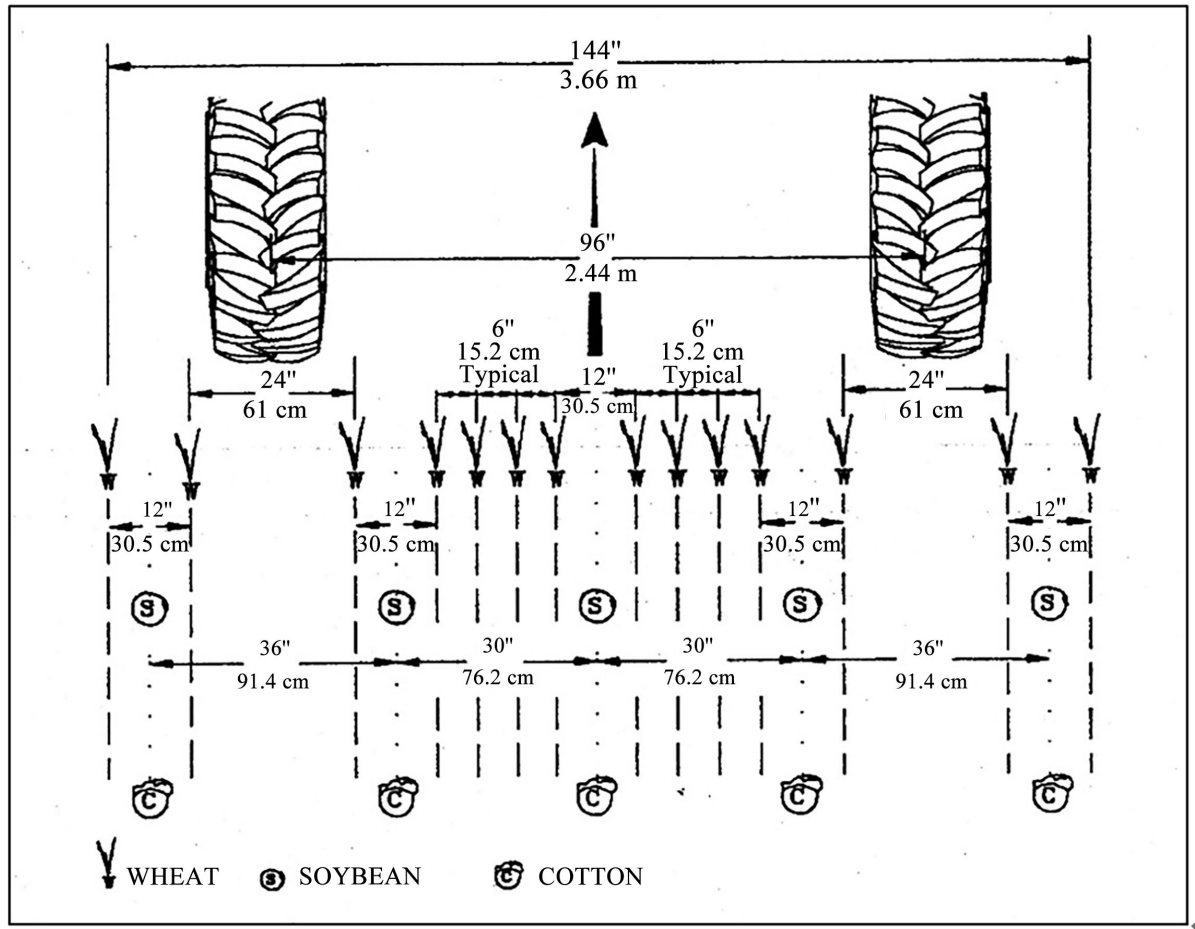

Figure 1. Narrow row interseeding system with $2.44 \mathrm{~m}$ wheel spacing, fourteen rows of wheat (15-cm spacing), and five rows of cotton (76-cm spacing). Adapted from Hood et al. (1991) [2].

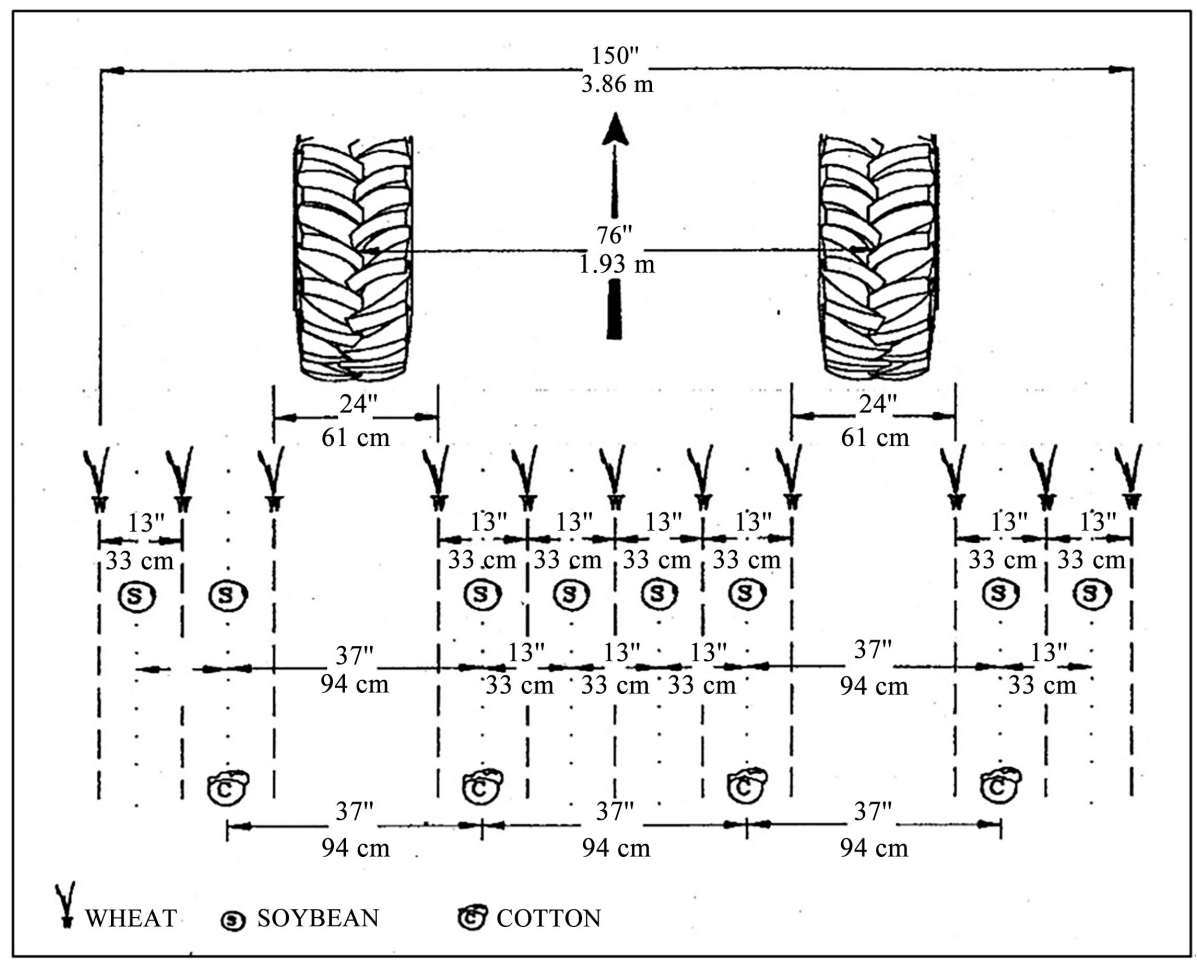

Figure 2. Wide row interseeding system with $1.93 \mathrm{~m}$ wheel spacing, eleven rows of wheat (33-cm spacing), and four rows of cotton (97-cm spacing). Adapted from Hood et al. (1991) [2]. 


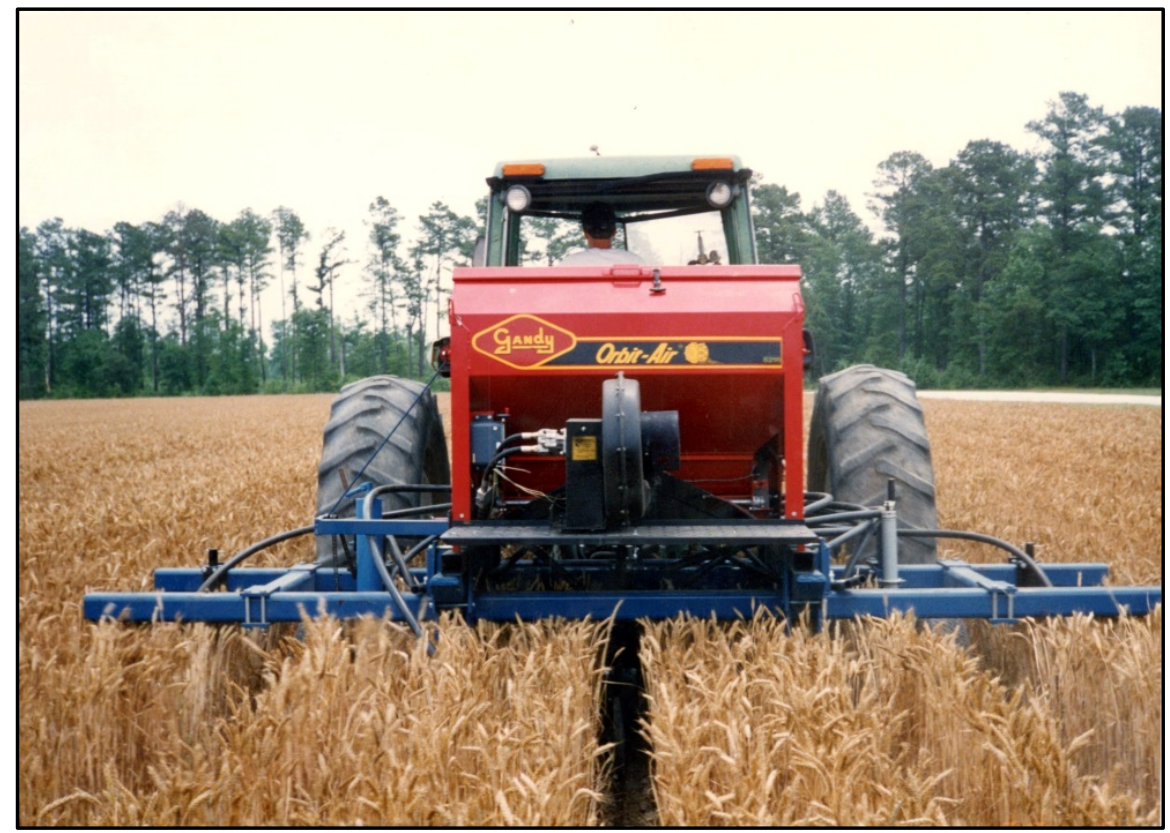

Figure 3. Interseeding narrow row cotton $(76-\mathrm{cm}$ spacing) into standing wheat using the Clemson interseeder planter/no-till drill [3].

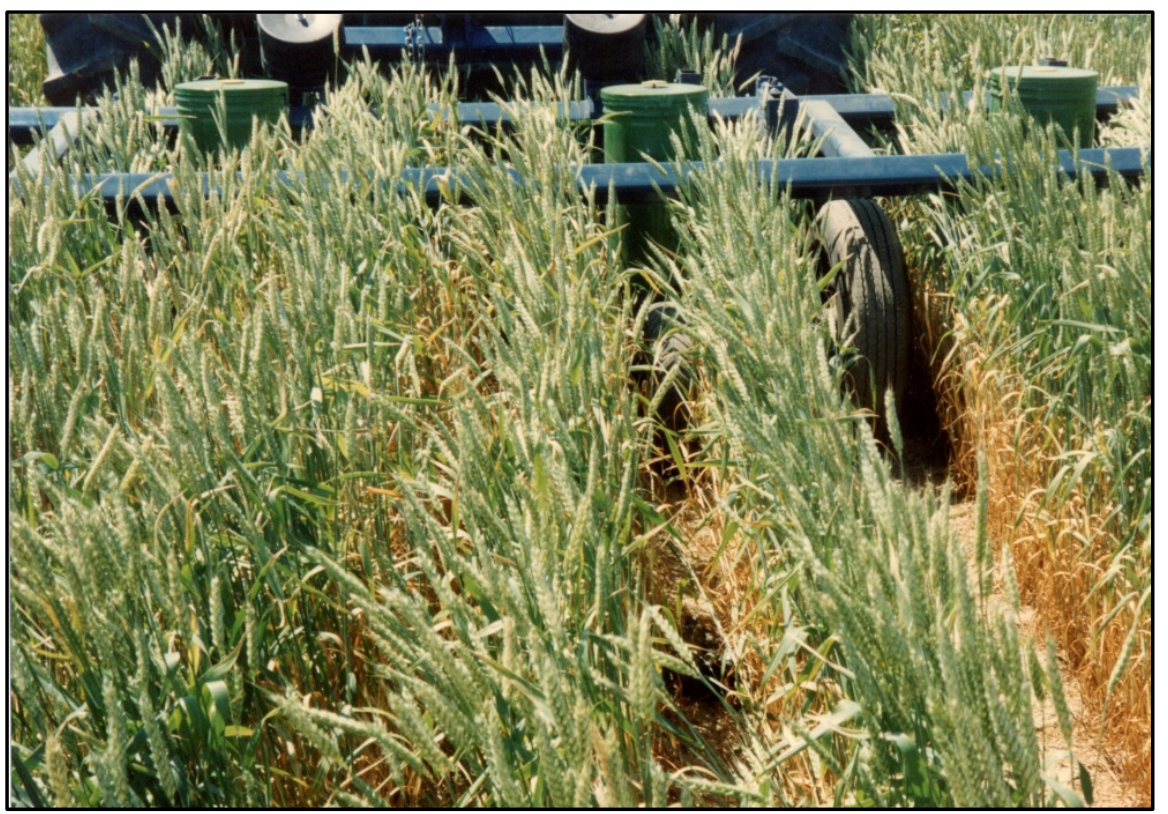

Figure 4. Interseeding narrow row cotton $(76-\mathrm{cm}$ spacing) into standing wheat, using John Deere 71 planter units (John Deere Co., Moline, IL, USA).

[2]. The plot area was provided with supplemental irrigation with a traveling-gun system on a limited basis to prevent loss of cotton stands in the interseeded plots while wheat was still actively growing. Fertilizer requirements were based on recommendations of the Clemson University Extension Service. Pest management practices for all treatments were based recommendations from the Agricultural Chemical Handbook from the Clemson University Extension Ser- 
vice. Cotton was machine harvested at maturity using a spindle picker around the first week in November. A Case/IH Model 2055 (Case IH Agriculture, Racine, WI, USA) adjustable-row picker equipped with five picking heads was used to harvest the cotton.

\subsection{Study 2}

Replicated field tests were conducted for two years (following Study 1), at the Clemson University Edisto Research and Education Center $\left(33.36^{\circ} \mathrm{N}, 81.32^{\circ} \mathrm{W}\right)$ near Blackville, SC, USA to evaluate two different interseeding row patterns: the narrow row system (Figure 1) and the wide row interseeding system (Figure 2) compared to narrow and wide row conventional cotton, and cotton planted in a terminated wheat cover crop (narrow and wide rows) on a coastal plain soil. The experiments were arranged in a randomized complete block design with six replications. Soil type for the study was a Varina loamy sand soil (clayey, kaolinitic, thermic plinthic Paleudults). This soil type represents a highly productive soil typically found in the southeastern Coastal Plain. Cotton variety "DES 119" was seeded at $1.3 \mathrm{~cm}$ depth at approximately 7 to 13 seeds per $\mathrm{m}$ row for the conventional plots and 13 to 20 seeds per $\mathrm{m}$ row in the interseeded and cover-crop treatments around mid-May in both years. Plots dimension were 3.9 by $30 \mathrm{~m}$. The plot area was provided with supplemental irrigation with a traveling-gun system on a limited basis to prevent loss of cotton seedlings in the interseeded plots while wheat was still actively growing. Wheat was harvested during the first week in June, with a grain combine equipped with a straw deflector, which placed the straw in the tractor and combine wheel tracks to aid in weed and residue management. This feature also prevented placing excess straw on top of the young cotton seedlings [2]. Plant height, population, height of lowest first boll, and stalk losses were determined prior to cotton harvest. Cotton was machine harvested at maturity using a spindle picker, around the first week of Novemberin both years. The Case/IH Model 2055 (Case IH Agriculture, Racine, WI, USA) adjustable-row picker was used to harvest the cotton in the different treatments.

For the interseeded plots (TRT 3 and 4), wheat was planted in the fall using the row patterns described in Figure 1 and Figure 2, after a deep tillage operation with a Paratill (Bingham Ag, Lubbock, TX, USA). The traffic lanes served as guides for the subsequent spring planting of cotton. The use of the established traffic lanes for cultural practices eliminated the need for spring deep tillage because compaction from equipment is limited to those lanes. In TRT 3 , four rows of $97-\mathrm{cm}$ cotton were interseeded into standing wheat (Figure 2) in mid-May of each year, using Clemson interseeder planter/no-till drill (Figure 3). For TRT 4, five rows of cotton were interseeded, with the three center rows spaced $76-\mathrm{cm}$ and the two outside rows spaced $91 \mathrm{~cm}$ from the adjacent inside rows (Figure 1). The $2.44 \mathrm{~m}$ wheel tracks accommodated wheel spacing for the grain combine as well as the cotton picker. The treatments for Study 2 are presented in Table 2. 
Table 2. Tillage and planting treatments at 76 and $97-\mathrm{cm}$ row spacing in Study 2.

\begin{tabular}{|c|c|c|c|c|c|}
\hline TRT & Fall tillage & Spring tillage & Planter & Interseeded $^{1}$ & Row spacing \\
\hline & & & & & $\mathrm{cm}$ \\
\hline 1 & None & Disk/Subsoil/Bed ${ }^{2}$ & J.D. $71(5)^{3}$ & No & 76 \\
\hline 2 & None & Disk/Subsoil/Bed ${ }^{2}$ & J.D. 7000 & No & 97 \\
\hline 3 & Paratill $^{4}$ & None & Interseeder $(\mathrm{N})^{5}$ & Yes & 76 \\
\hline 4 & Paratill $^{4}$ & None & Interseeder $(\mathrm{W})^{5}$ & Yes & 97 \\
\hline 5 & None & Subsoil/Plant ${ }^{6}$ & J.D. $71(5)^{3}$ & No & 76 \\
\hline 6 & None & Subsoil/Plant ${ }^{6}$ & J.D. 7000 & No & 97 \\
\hline
\end{tabular}

${ }^{1}$ Cotton interseeded into standing wheat. ${ }^{2}$ Conventional tillage consisted of a disk harrow followed by a subsoiler bedder operating 30- to $33-\mathrm{cm}$ deep followed by striking-off beds with bed knockers and planting the cotton. ${ }^{3}$ Five-row John Deere 71 planter units (John Deere Co., Moline, IL, USA) (Figure 4). ${ }^{4}$ Paratill (Bigham Ag, Lubbock, TX, USA) with $61 \mathrm{~cm}$ shank spacing operating 30- to $33-\mathrm{cm}$ deep. ${ }^{5} \mathrm{Clemson}$ interseeder planter/no-till drill [3]. $\mathrm{N}=$ narrow row (Figure 1) and $\mathrm{W}=$ wide row (Figure 2). ${ }^{6}$ Wheat was used a cover crop only and terminated in last week of April of each year, mowed, and cotton was planted on 76-or 97-cm row spacing with a KMC subsoiler (Kelly Manufacturing Co., Tifton, GA, USA) operating 30- to 33-cm deep mounted in front of a John Deere 7000 or John Deere 71 planter (John Deere Co., Moline, IL, USA) during the first week in May of each year.

To determine the effects of cropping systems on soil compaction, a microcomputer-based, tractor-mounted recording penetrometer was used to quantify soil penetration resistance [10]. Penetrometer data were collected immediately after cotton harvest for Study 2 in November of both years.

\section{Results}

\subsection{Study 1}

The cotton stands observed in both four-row $(97-\mathrm{cm})$ and five-row $(76-\mathrm{cm})$ interseeded cotton into standing wheat were excellent (data not shown). The overall stands of interseeded cotton planted with the Clemson interseeder were similar to those observed with the conventional John Deere 71 planters (John Deere Co., Moline, IL, USA). The narrow design of the Yetter Seeder Coulters (Yetter Farm Equipment, Colchester, IL, USA) on the Clemson interseeder, allowed the cotton to be interseeded between the $30-\mathrm{cm}$ wheat rows without damaging to the wheat crop. The controlled-traffic procedure kept the interseeded areas in the wheat crop areas non-compacted and friable.

Wheat yields ranged from 4698 to $5362 \mathrm{~kg} / \mathrm{ha}$. Cotton in the narrow-row, $76-\mathrm{cm}$ conventional plots (TRT 5) yielded $23 \%$ more than the conventional, 97-cm cotton row spacing (TRT 4) (Table 3). This is due to a deep tillage operation with Paratill, which disturbs a greater amount within the soil profile, compared to conventional subsoilers, without impacting the upper soil surface profile. There were no significant differences in yield among the narrow-row $(76-\mathrm{cm})$ interseeded cotton (TRT 2), wide-row (97-cm) interseeded cotton (TRT 1) and conventional wide-row full season cotton (TRT 4). 
Table 3. Wheat and cotton yields from wheat/cotton cropping system in Study $1^{1}$.

\begin{tabular}{ccc}
\hline Treatment No. & Wheat Yield & Cotton Yield \\
\hline 1 & \multicolumn{2}{c}{$\mathrm{kg} / \mathrm{ha}$} \\
\hline 2 & $5070 \mathrm{a}$ & $1938 \mathrm{~b}$ \\
3 & $4698 \mathrm{a}$ & $2236 \mathrm{~b}$ \\
4 & $4774 \mathrm{a}$ & $2252 \mathrm{~b}$ \\
5 & - & $2088 \mathrm{~b}$ \\
\hline
\end{tabular}

${ }^{1}$ Values in a column followed by the same letter are not significantly different at the $95 \%$ confidence level.

\subsection{Study 2}

Table 4 shows cone index values at three depth ranges in a cotton row and a traffic lane for each treatment at harvest for the second year of the study. Similar results were obtained in year one (data not shown). Low cone index values from the crop rows at harvest (less than $1034 \mathrm{kPa}$ in the top $30-\mathrm{cm}$ of the soil profile) indicate that the residual effect of deep-tillage operations will extend for an additional year using a controlled traffic interseeding cropping system. Similar results were obtained by the investigators on coastal plain soils [3] [11] [12]. This could result in a savings of $\$ 20$ to $\$ 25 /$ hectare. Cone index values above 1034 $\mathrm{kPa}$ generally reduce crop yield, and values above $2068 \mathrm{kPa}$ will stop root growth hrough the compacted layer [2]. The tire track zones in these studies were highly compacted, even in the top $15-\mathrm{cm}$ of the soil profile, which made interseeding cotton possible despite a rainfall event before planting cotton.

Cotton plant height, plant population and height of the lowest first boll for each treatment for Study 2 are shown in Table 5. In year one, cotton plant height varied greatly among treatments ranging from 0.7 to $1.02 \mathrm{~m}$ with TRT 4 being the shortest at $0.7 \mathrm{~m}$. The full season conventional cotton (TRT 1 and 2) plants were the tallest in both row spacings, at 1.02 and $0.89 \mathrm{~m}$, respectively. Cotton in the interseeded treatments (TRT 3 and 4) appeared to be shorter than cotton in the other treatments. Plant heights in the second year of the study ranged from 0.59 to $0.75 \mathrm{~m}$ with TRT 1 and 2 (conventional cotton production system) having significantly greater heights of 0.75 and $0.71 \mathrm{~m}$, which was similar to what was observed in year one. Plant heights in the full season conventional cotton (TRT 1 and 2) system, regardless of row spacing, were significantly taller than the cotton in the interseeded (TRT 3 and 4) or cover crop (TRT 5 and 6) treatments. In 2004, no differences were observed between the interseeded (TRT 3 and 4) and cover crop (TRT 5 and 6) treatments.

There were no significant differences in plant populations among treatments at harvest in year one across treatments (Table 5). Overall, plant populations in year two of the study across all treatments were higher than the year one. Plant populations for full season conventional cotton system (TRT 1 and 2) were low- 
er than the rest of the treatments at 7.9 and 8.8 plants $/ \mathrm{m}^{2}$ in the 76 and $97-\mathrm{cm}$ row spacings, respectively. Plant spacings ranged from 9.5 to 10.8 plants $/ \mathrm{m}^{2}$ in the interseeded (TRT 3 and 4) and cover crop (TRT 5 and 6) treatments.

Wheat stubble played an important role in determination of the height of the first boll. The average height of the first boll was significantly less in full season cotton (TRT 1 and 2) system than in the interseeded cotton (TRT 3 and 4). The first boll height in year one and two of the study was significantly lower in the full season conventional cotton (TRT 1 and 2). In contrast, the interseeded cotton had the highest first boll height in both years. Similar results were reported by Khalilian et al., 2018 [3]. Yield losses associated with the inability of the cotton picker to harvest bolls were the greatest for the full season cotton system (TRT 1 and 2). Previous research [3] has reported that for the full season cotton production system over $15 \%$ of the bolls formed on or below the fifth node which averaged $27 \mathrm{~cm}$ above the ground, whereas, in the conservation tillage system, less than $6 \%$ of bolls formed below the fifth node which averaged $41-\mathrm{cm}$. above the ground [3].

Plants in the interseeded (TRT 3 and 4) and cover crop treatments (TRT 5 and 6) terminated prematurely due to lack of available nitrogen around mid-August and were significantly shorter than in the full season cotton production system. Nitrogen is a critical plant nutrient for cotton during the growing season and is essential for maximizing cotton yield potential [13] [14]. Hutchinson et al. [15] reported that cotton after wheat required approximately $39 \mathrm{~kg} / \mathrm{ha}$ more nitrogen than conventional cotton after fallow and native vegetation to obtain similar cotton yields. Optimum yields were achieved at $78 \mathrm{~kg} / \mathrm{ha}$ nitrogen for cotton planted after native vegetation and $118 \mathrm{~kg} / \mathrm{ha}$ for cotton following wheat. All cotton plots in second year of the study received a total of $90 \mathrm{~kg} / \mathrm{ha}$ nitrogen. However, in year two of the study, above average rainfall during the growing season (762 $\mathrm{mm}$ from June to October) and/or nitrogen being tied up in the wheat residue during degradation could have contributed to significant nitrogen removal from the system for optimum crop growth for cotton planted in wheat stubble.

Wheat yields in year one ranged from 3181 to $3403 \mathrm{~kg} / \mathrm{ha}$ (Table 6). In year two, wheat yields in the interseeding system were significantly higher than year one, at 5199 and $5509 \mathrm{~kg} / \mathrm{ha}$ for TRT 3 and 4, respectively.

In year one of the study, cotton yields were not significantly different among treatments. In year two, there was no significant difference in cotton yield among interseeded into standing wheat two weeks before harvest (TRT 3 and 4) and cotton planted in killed cover crop (TRT 5 and 6) (Table 6). There was no significant difference in cotton yield between narrow-row $(76-\mathrm{cm})$ and wide-row $(97-\mathrm{cm})$ cotton for each cropping system in either year of the study. However, both wide and narrow-row full season cotton (TRT 1 and 2) yielded significantly higher than interseeded or cover crop cotton in year two. This could be attributed to insufficient nitrogen for the cotton in conservation cropping systems. 
Table 4. one index readings in a cotton row and a traffic lane for different treatments at three different depths below the soil surface after cotton harvest in year 2 of Study $2^{1}$.

\begin{tabular}{ccccccc}
\hline TRT & \multicolumn{3}{c}{ Cotton Row Depth $(\mathrm{cm})$} & \multicolumn{3}{c}{ Traffic Lane Depth $(\mathrm{cm})$} \\
\hline & $0-15$ & $15-30$ & $30-45$ & $0-15$ & $15-30$ & $30-45$ \\
\hline 1 & $324 \mathrm{c}$ & $655 \mathrm{~b}$ & $1386 \mathrm{~b}$ & $834 \mathrm{ab}$ & $2117 \mathrm{a}$ & $2027 \mathrm{bc}$ \\
2 & $483 \mathrm{ab}$ & $662 \mathrm{~b}$ & $1055 \mathrm{c}$ & $1096 \mathrm{a}$ & $2386 \mathrm{a}$ & $1786 \mathrm{bc}$ \\
3 & $338 \mathrm{c}$ & $876 \mathrm{a}$ & $1020 \mathrm{c}$ & $965 \mathrm{ab}$ & $2151 \mathrm{a}$ & $1965 \mathrm{bc}$ \\
4 & $524 \mathrm{a}$ & $952 \mathrm{a}$ & $1124 \mathrm{c}$ & $1193 \mathrm{a}$ & $2282 \mathrm{a}$ & $1675 \mathrm{c}$ \\
5 & $290 \mathrm{c}$ & $662 \mathrm{~b}$ & $1765 \mathrm{a}$ & $690 \mathrm{~b}$ & $2372 \mathrm{a}$ & $2620 \mathrm{a}$ \\
6 & $379 \mathrm{c}$ & $834 \mathrm{a}$ & $1544 \mathrm{ab}$ & $910 \mathrm{ab}$ & $2386 \mathrm{a}$ & $2144 \mathrm{~b}$ \\
\hline
\end{tabular}

${ }^{1}$ Values in a column followed by the same letter are not significantly different at the $95 \%$ confidence level.

Table 5. Plant height, plant population, and height of lowest boll as affected by selected treatments in Study $2^{1}$.

\begin{tabular}{|c|c|c|c|c|c|c|}
\hline \multirow[t]{2}{*}{ TRT } & \multicolumn{2}{|c|}{ Plant Height } & \multicolumn{2}{|c|}{ Plant Population } & \multicolumn{2}{|c|}{ First Boll Height } \\
\hline & Year 1 & Year 2 & Year 1 & Year 2 & Year 1 & Year 2 \\
\hline & \multicolumn{2}{|c|}{$\mathrm{m}$} & \multicolumn{2}{|c|}{ plants/row m } & \multicolumn{2}{|c|}{$\mathrm{cm}$} \\
\hline 1 & $1.02 \mathrm{a}$ & $0.75 \mathrm{a}$ & $6.9 \mathrm{a}$ & $7.9 \mathrm{~b}$ & $15 \mathrm{c}$ & $21 \mathrm{c}$ \\
\hline 2 & $0.89 \mathrm{ab}$ & $0.71 \mathrm{a}$ & $7.9 \mathrm{a}$ & $8.8 \mathrm{ab}$ & $14 \mathrm{c}$ & $21 \mathrm{c}$ \\
\hline 3 & $0.79 \mathrm{bc}$ & $0.60 \mathrm{~b}$ & $6.6 \mathrm{a}$ & $9.5 \mathrm{ab}$ & $23 \mathrm{a}$ & $34 \mathrm{a}$ \\
\hline 4 & $0.70 \mathrm{c}$ & $0.59 \mathrm{~b}$ & $8.2 \mathrm{a}$ & $9.8 \mathrm{a}$ & $23 \mathrm{a}$ & $33 a$ \\
\hline 5 & $0.95 \mathrm{a}$ & $0.60 \mathrm{~b}$ & $6.6 \mathrm{a}$ & $9.5 \mathrm{ab}$ & $20 \mathrm{~b}$ & $26 \mathrm{~b}$ \\
\hline 6 & $0.88 \mathrm{ab}$ & $0.56 \mathrm{~b}$ & $6.9 \mathrm{a}$ & $10.8 \mathrm{a}$ & $21 \mathrm{~b}$ & $27 \mathrm{~b}$ \\
\hline
\end{tabular}

${ }^{1}$ Values in a column followed by the same letter are not significantly different at the $95 \%$ confidence level.

Table 6. Wheat and cotton yields as affected by different treatments in Study $2^{1}$.

\begin{tabular}{ccccc}
\hline TRT & \multicolumn{2}{c}{ Wheat Yield } & \multicolumn{2}{c}{ Cotton Yield } \\
\hline & Year 1 & Year 2 & Year 1 & Year 2 \\
\hline 1 & \multicolumn{2}{c}{$\mathrm{kg} / \mathrm{ha}$} & \multicolumn{2}{c}{$\mathrm{kg} / \mathrm{ha}$} \\
\hline 2 & ---- & --- & $3510 \mathrm{a}$ & $4148 \mathrm{a}$ \\
3 & ---- & --- & $3505 \mathrm{a}$ & $4245 \mathrm{a}$ \\
4 & $3181 \mathrm{a}$ & $5199 \mathrm{ab}$ & $3237 \mathrm{a}$ & $3410 \mathrm{~b}$ \\
5 & $3403 \mathrm{a}$ & $5509 \mathrm{a}$ & $3295 \mathrm{a}$ & $3502 \mathrm{~b}$ \\
6 & ---- & ---- & $3342 \mathrm{a}$ & $3403 \mathrm{~b}$ \\
\hline
\end{tabular}

${ }^{1}$ Values in a column followed by the same letter are not significantly different at the $95 \%$ confidence level.

\section{Conclusions}

Cotton can be interseeded successfully into standing wheat, and it will mature in time for a productive harvest. Based on these research results, interseeding 
should be conducted following a good rainfall before planting cotton in mid-May. Supplemental irrigation is required on a limited basis to prevent loss of cotton stands in the interseeded plots while wheat is actively growing. Wheat yields were not affected by interseeding system. In Study 1, the narrow-row $(76-\mathrm{cm})$ conventional-tillage cotton yielded $23 \%$ more than conventional-tillage $(97-\mathrm{cm})$ cotton. There was no significant difference in cotton yield due to row spacing in either. No significant yield differences were observed for cotton interseeded into standing wheat, conventional full season cotton, or cotton planted in killed wheat cover crop in Study 1 and the first year of the Study 2. Both wide-row and narrow-row mono-crop cotton yielded significantly higher than the interseeded or cover crop cotton in year two of the study 2 .

Deep tillage performed before small grain planting benefitted the subsequent cotton when used with the controlled traffic patterns associated with the interseeding system. The residual effect of deep tillage operations was extended for one additional year when interseeding was implemented. The two conservation cropping practices, wheat used as a cover crop and interseeding, have shown considerable promise for reducing energy requirements, soil erosion and cotton plant damage due to wind and blowing sand. These research results show the potential benefits of using interseeding and cover crop conservations practices to meet compliance standards without sacrificing profit. Limitations of this technology include if moisture is limiting at the time of interseeding cotton planting when wheat is actively removing water from the soil; then interseeding should be delayed until a sufficient rain event occurs which could reduce cotton yield potential [3]. In addition, the interseeding equipment used in this research project requires a specialized planter with narrow row units for interseeding cotton into standing wheat crop which growers may not have in their inventory [3]. More research is also needed on the best management options for pest management in the interseeding production system.

\section{Acknowledgements}

Technical Contribution No. 6665 of the Clemson University Experiment Station; this material is based upon work supported by NIFA/USDA, under project number SC-1700539.

\section{Disclaimer}

Mention of a trade name does not imply endorsement of the product by Clemson University to the exclusion of others that might be suitable.

\section{References}

[1] United States Department of Agriculture and National Agricultural Statistics Service (2017) Crop Production Summary. https://www.usda.gov/nass/PUBS/TODAYRPT/cropan17.pdf

[2] Hood, C.E., Khalilian, A., Palmer, J.H., Garrett, T.R. and Hayes, J.C. (1991) 
Double-Cropping Interseeding System for Wheat, Soybean and Cotton. Applied Engineering in Agriculture, 7, 530-536. https://doi.org/10.13031/2013.26263

[3] Khalilian, A., Marshall M.W., Williams, P.B., Greene, J.K. and Porter, P.M. (2018) Cotton Production Systems for Soil and Energy Conservation in Coastal Plain. American Journal of Plant Sciences, 9, Article ID: 85508.

[4] Khalilian, A., Gamer, T.H., Hood, C.E. and Sullivan, M.J. (1991) A Progress Report on Cotton Production Systems for Soil and Energy Conservation. 1991 Proceedings of the Beltwide Cotton Conference, San Antonio, January 8-12 1991, 449-452.

[5] Rogers, N.K., Buchanan, G.A. and Johnson, W.C (1976) Influence of Row Spacing on Weed Competition in Cotton. Weed Science, 24, 410-413.

[6] Heitholt, J.J., Pettigrew, W.T., and Meredith Jr., W.R. (1991) Light Interception and Lint Yield of Narrow-Row Cotton. Crop Science, 32, 728-733. https://doi.org/10.2135/cropsci1992.0011183X003200030030x

[7] Hawkins, B.S. and Peacock, H.A. (1973) Influence of Row Width and Population Density on Yield and Fiber Characteristics of Cotton. Agronomy Journal, 65, 47-51. https://doi.org/10.2134/agronj1973.00021962006500010014x

[8] Jost, P.H. and Cothren, J.T. (2000) Growth and Yield Comparisons of Cotton Planted in Conventional and Ultra-Narrow Row Spacings. Crop Science, 40, 430-435. https://doi.org/10.2135/cropsci2000.402430x

[9] Boquet, D.J. (2004) Cotton in Ultra-Narrow Row Spacing. Agronomy Journal, 9, 279-287. https://doi.org/10.2134/agronj2005.0279

[10] Marshall, M.W., Williams, P.B., Nafchi, A.M., Maja, J.M., Payero, J., Mueller, J.D. and Khalilian, A. (2016) Influence of Tillage and Deep Rooted Winter Cover Crops on Soil Properties, Pests, and Yield Responses in Cotton. Open Journal of Soil Sciences, 6, 149-158. https://doi.org/10.4236/ojss.2016.610015

[11] Khalilian, A., Hood, C.E., Palmer, J.H., Garner, T.H. and Bathke, G.R. (1991) Soil Compaction and Crop Response to Wheat/Soybean Interseeding. Transactions of the ASAE, 34, 2299-2303. https://doi.org/10.13031/2013.31871

[12] Khalilian, A., Jones, M.A., Bauer, P.J. and Marshall, M.W. (2017) Comparison of Five Tillage Systems in Coastal Plain Soils for Cotton Production. Open Journal of Soil Science, 7, 245-258. https://doi.org/10.4236/ojss.2017.710018

[13] Read, J.J., Reddy, K.R. and Jenkins, J.N. (2006) Yield and Fiber Quality of Upland Cotton as Influenced by Nitrogen and Potassium Nutrition. European Journal of Agronomy, 24, 282-290. https://doi.org/10.1016/j.eja.2005.10.004

[14] Bronson, K.F., Onken, A.B., Keeling, J.W., Booker, J.D. and Torbert, H.A. (2001) Nitrogen Response in Cotton as Affected by Tillage Systems and Irrigation Level. Soil Science Society of America Journal, 65, 1153-1163. https://doi.org/10.2136/sssaj2001.6541153x

[15] Hutchinson, R.L., Breitenbeck, G.A., Brown, R.A. and Thomas, W.J. (1994) Effects of Tillage Systems and Cover Crop on Nitrogen Fertilizer Requirements of Cotton. 1994 Proceedings of Southern Conservation Tillage Conference for Sustainable Agriculture, Columbia, 7-9 June 1994, 70-76. 